\title{
Collaboration on Trial: New Source Material on Soviet Postwar Trials against Collaborators
}

\author{
Tanja Penter
}

Jeffrey W. Jones's article on perceptions of collaboration in Rostov-onDon presents interesting new research on a topic that was taboo in Soviet times and has hardly been studied to this day. The main focus of recent studies in the west has been directed at military and police collaboration and we still know almost nothing about other spheres of collaboration, such as collaboration in the local administration or economic collaboration. ${ }^{1}$ Jones gives several examples that show the wide range of everyday collaboration, involving nearly "every family" and including housing administrators who handed over lists of communists and Jews to the Nazis and school inspectors who distributed fascist literature. In accordance with the sources he uses, Jones analyzes the different perceptions of collaboration in Soviet society during and after the war. Therefore, he reveals a picture based on "representations and reflections of reality, but not reality itself." Jones mainly evaluates three different discourses on collaboration: the inner party discussions, the propaganda in the local press, and the opinions of the popular classes. This is no doubt a legitimate and reasonable approach. It is not the author's intention to clarify the empirical dimension of collaboration in Rostov-on-Don. And everybody will agree with Jones that today it is impossible to determine the actual scale of collaboration under German occupation, first because of the unclear definition of the phenomenon itself and second because of the lack of sources. Nevertheless, Jones provides interesting numbers from the party archive about people who worked for the Germans in the fields of housing, trade, finance, and education. He shows that a relatively high percentage of qualified specialists worked for the Germans and that only a small number were replaced in the postwar years, mainly because of a lack of quali-

I want to thank Martin Dean and Vadim Altskan for their support.

1. See Martin C. Dean, Collaboration in the Holocaust: Crimes of the Local Police in Belorussia and Ukraine, 1941-44 (New York, 2000); Frank Golczewski, "Organe der deutschen Besatzungsmacht: Die ukrainischen Schutzmannschaften," in Wolfgang Benz, Johannes Houwink ten Cate, and Gerhard Otto, eds., Die Bürokratie der Okkupation: Strukturen der Herrschaft und Verwaltung im besetzten Europa (Berlin, 1998), 173-96; Dieter Pohl, "Ukrainische Hilfskräfte beim Mord an den Juden," in Gerhard Paul, ed., Die Täter der Shoah: Fanatische Nationalsozialisten oder ganz normale Deutsche? (Göttingen, 2002), 205-34; Dieter Pohl, Nationalsozialistische Judenverfolgung in Ostgalizien 1941-1944: Organisation und Durchführung eines staatlichen Massenverbrechens (Munich, 1997); Richard Breitman, "Himmler's Police Auxiliaries in the Occupied Soviet Territories," in Simon Wiesenthal Center Annual 7 (1990): 23-39; and Peter Black, "Die Trawniki-Männer und die 'Aktion Reinhard,'" in Bogdan Musial, ed., "Aktion Reinhardt": Der Völkermord an den Juden im Generalgouvernement 1941-1944 (Osnabrück, 2004), 309-52. For a study on administrative and economic collaboration in the Donbas coal mining region, based on Soviet postwar collaboration trials, see Tanja Penter, "Die lokale Gesellschaft im Donbass unter deutscher Okkupation 19411943," in Beiträge zur Geschichte des Nationalsozialismus, vol. 19, Kooperation und Verbrechen: Formen der "Kollaboration" im östlichen Europa, 1939-1945 (Göttingen, 2003), 183-223.

Slavic Review 64, no. 4 (Winter 2005) 
fied personnel to take their positions. Most interestingly, the majority of the local specialists, as we learn from Jones's numbers, were not evacuated but remained under German occupation - contrary to the official Soviet narrative and historiography about evacuation. We find the same situation in the Donbas region, where a considerable number of specialists in the coal mining industry remained in occupied territory and worked for the Germans.

One aspect that is not treated in Jones's article is the postwar conviction of collaborators by Soviet regional military tribunals. I would like to draw attention to new source material-records of trials against collaborators - that is now available, at least for some former occupied Soviet territories, and I will focus on the question of what these trial records can tell us about the phenomenon of collaboration and about the way the Soviet government dealt with collaboration in the postwar period. This will hopefully add a further perspective to Jones's impressive and rich local study.

According to a recent publication of the Russian Federal Security Service, during the years from 1943 to 1953, more than 320,000 Soviet citizens were arrested in the Soviet Union for collaborating with the Germans. In the Rostov-on-Don region, 12,196 people were arrested by the KGB during that time. ${ }^{2}$ Though the trial records are still located in the former KGB-archives of the successor states of the Soviet Union and are mostly not accessible either for foreign or for domestic researchers, the archive of the United States Holocaust Memorial Museum in Washington holds a unique microfilm collection of Soviet postwar trials related to the Holocaust. So far this collection consists of several thousand trials of collaborators from the Baltic states, Ukraine, Moldova, Uzbekistan, and Kazakhstan. ${ }^{3}$ The trials took place in the period from 1943 until the 1980s, and they reflect the professionalization of the organs of justice that took place during this time period, evident in the more careful investigations conducted and more professional methods applied.

These trial records represent an extremely valuable resource for three reasons. First, they contain detailed descriptions of the Holocaust in different local settings, towns, and villages and of life in ghettos and camps. Sometimes they even contain primary documents from the occupation and quite often they contain reports of the Extraordinary Commission. In

2. See O. B. Mozokhin, "Statistika repressivnoi deiatel'nosti organov bezopasnosti SSSR na period s 1921 po 1953 gg." Available on the Federal'naia sluzhba bezopasnosti (FSB) web site at http://www.fsb.ru/new/mozohin.html (last consulted 1 July 2005). For Ukraine, a recent empirical analysis from the Ukrainian historian V. M. Nikol's'kii, based on material from the Kievan Central Sluzhba bezpeki Ukrainy-archive, gives us some preliminary numbers. According to this, between the years 1943 and 1957 the NKVD arrested 93,690 collaborators in the Ukraine. See V. M. Nikol's'kii, Represyvna diial'nist' orhaniv derzhavnoï bezpeky SRSR v Ukraïni (kinets' 1920-kh-1950-ti rr.): Istoryko-statystychne doslidzhennia; monohrafia (Donetsk, 2003), 206-24.

3. As a Pearl Resnick Postdoctoral Fellow at the Center for Advanced Holocaust Studies at the United States Holocaust Memorial Museum for nine months, I worked with the museum's collection of trials related to the Holocaust in Ukraine and tried to provide the first systematic analysis of these trials. 
several cases, the trial records might represent the only source documenting the existence of ghettos and camps or mass executions. For example, in Donetsk the trial of the head of the local administration is the only source, aside from a few survivor testimonies, suggesting the existence of a ghetto in this city. ${ }^{4}$ Second, the trial records tell us something about the personal profile of local collaborators and their motives. And third, they express the perception and definition of collaboration by those in power, and they show us how the Soviet government in the postwar years dealt with collaboration. Of course, the trial records alone do not allow us to draw any conclusions about the actual scale of collaboration, because they do not tell us anything about those who were executed without trial, were wrongfully accused, or not tried at all (and why not).

So, what do the trial records tell us about wartime collaboration and postwar perceptions of collaboration? First, they reflect, in the same way as the material Jones used, the Soviet regime's extremely broad understanding of collaboration. Along with real war criminals who directly participated in mass murder there are also trials of minor employees of the Germans, like women who cooked and cleaned for SS units or even several former "Ostarbeiter" who spread rumors about the allegedly very good living conditions in Germany. Even when a defendant acted at the risk of losing his life there was no mitigating effect, as several trials against Jewish defendants, mostly members of the Jewish councils, show. Not only people who actively supported the Germans fell under suspicion of disloyalty, as Jones shows, but everyone who was exposed to German propaganda and had contact with Germans was suspect, like Soviet POWs, repatriated "Ostarbeiter," and anyone who stayed in occupied territory.

The trial records, as mentioned above, also provide some personal data about the convicted collaborators, including date and place of birth, place of residence, profession, nationality, citizenship, membership in the Communist Party, level of education, social background, former convictions, the defendant's military participation in World War II, and information about the defendant's family members. This information, which seems to be quite reliable, can be analyzed empirically to obtain some conclusions about the collective biography of collaborators. But we also have to be aware that the profile of convicted collaborators may have depended as well on either the German recruitment policies or, later, on the Soviet bias in bringing charges.

Generally, if we look at the biographies of collaborators we can see that they sometimes fought in the Red Army before and after they had collaborated with the Germans and sometimes even received high military awards (which they normally had to return after their conviction). It was not rare that policemen were recruited from among Soviet POWs. This was especially true for the so called "Travniki"-men-Ukrainian policemen who were trained in a special camp close to the town of Travniki in

4. See, for trials in Donetsk, Penter, "Die lokale Gesellschaft im Donbass unter deutscher Okkupation," 183-223. 
the Lublin district and who were deployed as guards in the death camps. ${ }^{5}$ From this we can conclude that often collaborators did not act primarily out of ideological motivations. And this also shows that the official Soviet representation, which tended to separate the Soviet population into "collaborators" and "resisters," did not correspond to the much more complex wartime reality. Quite often there was no clear line between "collaboration" and "loyalty" in peoples' actions, but rather "moral gray zones." This also means that phenomena like "collaboration," "resistance," and also "forced labor" were in fact much more interrelated than historians have thought so far and should be studied not separately but in conjunction. Jones also demonstrates the complexity of the phenomenon, contrary to the formerly prevailing binary vision of resistance and collaboration.

When it comes to the question of motives for collaboration, we depend on the defendant's own evidence, or rather its interpretation by Soviet officials. Therefore, the statements have to be handled with special care. Nevertheless, some conclusions are possible. Most notably, it seems that older clichés have to be revised. At least for central and eastern Ukraine, Ukrainian nationalistic attitudes seem to be of minor importance for the policemen. Much more often, pragmatic and material considerations, especially the fact that local policemen received the same food rations as German soldiers, played the main role. Some of the defendants, especially POWs, admitted the motivation of self-preservation; others said that they tried to escape forced deportation to Germany. In one case, the defendant even mentioned that his wife forced him to join the police to make a better living.

Anti-Semitism must have been a motivation for some of the collaborators' actions, but, interestingly, this was not mentioned in any of the trials at all. The entire question of anti-Semitic attitudes was ignored in the trials. Even the term anti-Semitism failed to be mentioned in a single trial. This shows the regime's problems and ambivalence towards manifestations of popular anti-Semitism at a time when an anti-Semitic wave swept through Ukraine's major cities. ${ }^{6}$ It was also typical for the postwar Soviet Union that the Jewish memory discourse about the Holocaust was widely suppressed. Instead, the official narrative touted the suffering of all nations during the war and the heroic victory. Despite the immense number of Jews murdered, Soviet accounts in general ignored, played down, or universalized the Holocaust. The number of Jewish victims was generally minimized in Soviet accounts and included as a rather small part in the death of 20 million Soviet citizens. The word Holocaust did not enter Russian usage until the 1990s. Only quite recently have the first studies on the Holocaust in Ukraine appeared in contemporary independent

5. See P. Black, "Die Trawniki-Männer und die 'Aktion Reinhard," 309-52.

6. See, for popular anti-Semitism in postwar Ukraine, Hiroaki Kuromiya, Freedom and Terror in the Donbas: A Ukrainian-Russian Borderland, 1870s-1990s (Cambridge, 1998), 198; and Amir Weiner, Making Sense of War: The Second World War and the Fate of the Bolshevik Revolution (Princeton, 2001). 
Ukraine, thanks to the establishment of centers for Holocaust studies in Kiev and Khar'kov, and the very recently opened center in Dnipropetrovs'k. ${ }^{7}$ In the trial records, Jewish victims were mostly referred to as "peaceful Soviet citizens." Only from the testimonies of witnesses and defendants do we learn that the victims were in fact Jews. Furthermore, official Soviet documents indicate a certain hierarchy of victims when they speak of "the murder of partisans, communists, Soviet activists, and the destruction of entirely innocent Soviet citizens." The sentences assigned to war criminals also reflect this hierarchy of victims.

Unexpectedly, most of the defendants had not been convicted and repressed previously under Soviet power. So the hypothesis that the collaborators hated the Soviet government because of their experience of repression does not always hold true. ${ }^{8}$ The Soviet authorities, however, tried to establish the image that collaborators had anti-Soviet and criminal backgrounds. In fact, the collaboration of Soviet elites shows the immense loyalty problem that the Soviet government faced in the occupied territories.

How did the Soviet state deal with collaborators? To what extent were the war crimes trials political trials? We see that in the Soviet Union several of the war crimes trials were staged in the manner of show trials, for example, the first trial against collaborators in Krasnodar in 1943. And several show trials were organized in western Ukraine from the late 1940s against underground activists of the Organization of Ukrainian Nationalists in order to mobilize the population for the active struggle against Ukrainian nationalists. ${ }^{9}$ But the majority of the trials against collaborators in the 1940s and early 1950s under Iosif Stalin were not show trials. In most cases they were not even public. These trials often convicted real war criminals and fulfilled political functions at the same time, which is probably also true for most of the war crimes trials in the west. Unlike the earlier Soviet show trials during the 1930s where innocent people were convicted for purely political reasons, in the postwar Soviet war crimes trials, often real criminals were sentenced.

In comparing the Soviet trials to western trials, we can observe that in the Soviet Union there existed a specific definition of justice, guilt, and collaboration. There was a specific hierarchy of charges, with "homeland

7. See for example V. M. Koval', "Natsists'kyi henotsyd shchodo evreïv ta ukraïns'ke naselennia (1941-1944 rr.)," Ukrains'kyi istorychnyi zhurnal, 1992, no. 2: 25-32; S. Ia. Elizavets'kyi, "Evreī v antyfashysts'komu opori i radjans'komu pidpil'no-partyzans'komu rusi v Ukraïni," Ukrä̈ns'kyi istorychnyi zhurnal, 1995, no. 3:59-73; S. Ia. Elizavets'kyi, Katastrofa i opir ukraïns'koho evreistva (1941-1944): Narysy z istoriï Holokostu i opore v Ukraïni (Kiev, 1999); Iu. M. Liakhovitskii, Zheltaia kniga: Svidetel'stva, fakty, dokumenty o natsistskom genotside evreiskogo naseleniia Khar'kova v period okkupatsii, 1941-1943, vol. 3 (Khar'kov, 1994); A. I. Kruglov, Iu. M. Liakhovitskii, and Iu. G. Subocheva, eds., Evreiskii genotsid na Ukraine v period okkupatsii v nemetskoi dokumentalistike, 1941-1944 (Khar'kov, 1996); A. Kruglov, Katastrofa ukrainskogo evreistva 1941-1944 gg.: Entsiklopedicheskii spravochnik (Khar'kov, 2001).

8. See Kuromiya, Freedom and Terror in the Donbas, 283.

9. See Amir Weiner, "War Crimes Trials and Communal Policing: Western Ukraine, 1940s-1950s" (paper, Workshop on Soviet and Eastern European War Crimes Trials, United States Holocaust Memorial Museum, Washington, D.C., June 2005). 
betrayal" reigning at the top, even above "crimes against humanity." Especially severe were actions that emerged out of a "hostile attitude towards Soviet power," as they are called in the trial documentation. Thus, from several trials against Ukrainian nationalists we get the impression that, in the understanding of the Soviet authorities, it was worse to be a Ukrainian nationalist than to participate in the murder of hundreds of Jews-it would be interesting to compare this to the conviction of cossacks in the Rostov region. Interestingly, the same loyalty standards were applied to defendants from the new western Ukrainian territories, which only became part of the Soviet Union in 1939, as for those from the old Soviet Ukrainian territories. A letter of complaint from a former policeman from the Tarnopil' region who was sentenced to twenty-five years of forced labor shows the confusion regarding the loyalty question in western Ukraine: "I come from western Ukraine and from my early youth I grew up with the awareness that my homeland is (panskaja) Poland, and the hatred of the Poles against the Ukrainian people strengthened in me this growing holy feeling of my homeland. And when I lost my work under German occupation in 1941 I was forced to serve in the police, but I did it not out of ideological persuasion but to make a living. Accordingly, I was entirely unaware of betraying my homeland, as I have lived in this new homeland for only one year. And this consciousness could not arise at all, because in such a short period of time it could not erupt into my thinking, into my crippled consciousness, which was corrupted by antiSoviet bourgeois propaganda. The judge who sentenced me did not consider this." 10

It also seems to be characteristic for the Soviet trials that the defendants are assessed with regard to their long-term loyalty towards the Soviet government and not only convicted for a single crime. So, if the defendant had the right social background and prewar biography or fought in the Red Army after he had collaborated, this could have a mitigating effect in his trial. The example of a Travniki-man shows this: in 1949 in Kiev, this Travniki-man, who according to German documents "had proven himself in several actions against Jews and in partisan combat," was given the relatively minor sentence of fifteen years of forced labor, because after the collaboration he served in the Soviet Army. He was wounded twice and obtained several military awards. During the trial the defendant's advocate argued that the defendant thereby "had partly made up for his guilt towards his homeland." "Also the family profiles of the defendants were involved in the trials, which seems to be unique for Soviet war crimes trials. If the defendant's father, for example, was a former kulak, this could have a negative impact. If a brother was fighting in the Red Army, this could be positive.

In the relatively few cases of female defendants, it is considered in the indictment whether these women had sexual relationships with German men. And, according to Jones, this motif of women who "betrayed the

10. United States Holocaust Memorial Museum, RG 31.018M, reel 24, delo 33533. 11. Ibid., reel 2, delo 39455 . 
motherland with their bodies" was used in the party press. Interestingly, in the case of male defendants, testimony regarding the raping of women is rarely part of the indictment. In the Soviet Union, it was also not explicitly included in any of the legal regulations dealing with war crimes.

If we return to the question whether the Soviet war crimes trials served justice, the overall picture is rather contradictory. On the one hand, we see real war criminals, like policemen who directly participated in mass killings, sentenced to death or twenty-five years of forced labor. And we also see that real war criminals sometimes could get a minor sentence because of mitigating factors. On the other hand, we see that Soviet citizens who, in a western understanding, were not war criminals at all, like former "Ostarbeiter" or specialists who helped the Germans to rebuild destroyed industries, were also sentenced to twenty or twenty-five years of forced labor. Unfortunately, we do not know how many of the convicted collaborators committed real crimes and how many were tried mainly for political reasons. Jones reveals the same picture, with different standards being applied to members of the Communist Party and to ordinary Soviet citizens. The arbitrary nature of convictions shows that the regional military tribunals had a certain freedom of action in their decisions, and also the relevant legal regulations left plenty of room for flexibility. So, the continuing question would be how far these arbitrary convictions depended on the influence of individuals or on regional structures and different regional political cultures in Ukraine.

A further important aspect reflected in the trial records is public participation and interaction in the denunciation and conviction of collaborators. As Jan Gross and Martin Dean have rightly pointed out, the crimes and betrayals of the collaborators took place in a neighborly context, which made them morally even worse in the public perception. ${ }^{12}$ There was considerable public participation in the denunciation of collaborators. Sometimes the local population even took the initiative in arresting collaborators and handing them over to the NKVD. Furthermore, in talking to Ukrainians today we learn that many people knew about the trials against local collaborators from reports of witnesses who gave evidence at the trials or by word-of-mouth. ${ }^{13}$ In most cases the trials were carried out at the place where the crimes were committed. So the Soviet trials had a double function. On the one hand they were a demonstration of Soviet power and intended to punish disloyal behavior and to bring the population in line. In the new western Ukrainian territories they also served the aim of Sovetization. ${ }^{14}$ On the other hand, it would be too easy to interpret

12. See Jan T. Gross, Neighbors: The Destruction of the Jewish Community in Jedwuabne, Poland (Princeton, 2001); and Martin Dean, "The 'Local Police' in Nazi-Occupied Belarus and Ukraine as the 'Ideal Type' of Collaboration: In Practice, in the Recollections of Its Members and in the Verdicts of the Courts" (paper, Nord Ost Institut, Lüneburg, Germany, 15 November 2003).

13. For example, in several interviews with local people in the Donbas region who lived under occupation, it came out that they remembered postwar trials where they were not personally involved.

14. See Amir Weiner, "War Crimes Trials and Communal Policing." 
the Soviet trials as mere examples of the abuse of justice in a totalitarian state. As it appears to me, the trials also satisfied the strong desire for revenge, order, and the reestablishment of old hierarchies on the local level. So the trials were not simply something directed and forced on the population from above but expressed an interaction between the Soviet authorities and the local communities. And they had an important symbolic meaning for these local communities.

Furthermore, the military tribunals provided a limited podium for alternative memory discourses that differed from the official Soviet discourse. While the Soviet government in the immediate postwar years tried to establish an official memory discourse on World War II that had very little in common with the real experiences and memories of the population who lived under German occupation, alternative war experiences were addressed in the trials. Not only was the mass murder of the Jews openly discussed, but also the forced deportations of workers to Germany and local pogroms against Jews and Poles. And the interesting follow-up question would be, to what degree were both the local demand for trials and the way the Soviet authorities responded to it influenced by older imperial Russian and early Soviet traditions (revolutionary tribunals) or by the big trials in the west, like the Nuremburg trials, which were widely reported in the Soviet press.

Finally, Jones's article shows us again the great potential of local studies, based on local archival materials, and the important influence these local and regional factors had during the period of German occupation and during the postwar years. But at the same time, the question arises of the representativeness of this Rostov-on-Don case study for perceptions of collaboration in the Soviet Union. In many respects, Rostov-on-Don, with its relatively short period of occupation and its cossack traditions, seems to be a very specific case. In Ukraine the diversity of the regions constitutes an important factor for the historical development of the country to this day. This was noticeable again during the recent presidential elections in Ukraine. And the lines of social and interethnic conflicts within local societies sometimes differed widely in the Ukrainian regions. Comparing trials against collaborators in different Ukrainian regions, one notices differences in the way collaboration functioned and the way it was dealt with in the postwar years. First, it seems striking that there were many more people arrested in the western Ukrainian territories (in proportion to the population), where the Soviet government faced bigger loyalty problems than in the old Soviet territories. ${ }^{15}$ Furthermore, the personal profile of the tried collaborators varied in different regions. For example, in the eastern Ukrainian Donetsk region, due to the ethnic composition of the population, a large proportion of the defendants were ethnic Germans (22 percent) and Russians (21 percent); only half of them were Ukraini-

15. While the old Soviet Ukrainian territories constituted three-quarters of Ukraine's 41 million population, western Ukraine constituted only one-quarter. Nevertheless, out of nearly 82,000 people arrested during the years $1946-1953$, more than half (58 percent) were arrested in western Ukraine. See Nikol's'kii, Represyvna diial'nist', 572-73. 
ans. ${ }^{16}$ There the so-called Ukrainian auxiliary police was much less Ukrainian than its name implied. In western Ukraine, on the other hand, the convicted policemen were more often members of Ukrainian nationalist organizations, which was more seldom the case in central and eastern Ukraine. Another important result of this comparison is that collaboration was a broad phenomenon in all Ukrainian regions and was not necessarily connected to Ukrainian nationalist attitudes.

Local and regional studies can help us to revise old stereotypes and come to a deeper understanding of Soviet society in wartime and postwar times. Hopefully Jones's study lays the groundwork for more research on this fascinating topic in the future.

16. V. M. Nikol's'kii, "Orhany derzhavnoï pezpeky na Donechchyni v roky velykoï viiny: Statystyka dii," Istorychni i politolohichni doslidzhennia, 2000, no. 1:156-58. 